\title{
ADDITIONAL EFFECT OF TRIGGER POINT THERAPY AND MYOFASCIAL RELEASE ON SECOND STAGE FROZEN SHOULDER AMONG INDUSTRIAL WORKERS
}

\author{
Gopal Nambi S, ${ }^{1}$ Walid Kamal M. Abdelbasset ${ }^{1,2}$ \\ ${ }^{1}$ Department of physical therapy and health rehabilitation, College of Applied Medical Sciences, \\ Prince Sattam Bin Abdul Aziz University, Al-Kharj, Saudi Arabia \\ ${ }^{2}$ Department of physical therapy, Kasr Al-Aini Hospital, Cairo University, Egypt
}

Primljen/Received 30. 04. 2017. god.

Abstract: Background and Purpose: Frozen shoulder is a common condition commonly affecting $2-5 \%$ of the industrial population typically between 40 and 60 years of age. Most of the studies were analysed the individual interventions and did not investigate the combination of interventions. The purpose of this study is to find two different forms of massage techniques Trigger Point therapy and Myofascial release in second stage of Frozen Shoulder to reduce pain and improve the Range of motion. Subjects: 30 subjects working in industry with unilateral second stage frozen shoulder lasting 3 months or more and $25 \%$ decrease in passive joint mobility relative to the non affected side were enrolled in this study. Methods: Subjects who were willing to participate in the study and to fulfil the inclusion and exclusion criteria were included in the study and they were divided into two Groups (A and B) randomly. Group A was treated with Trigger Point therapy, Myofascial release, Scapula Stabilization Exercises, and Interferential Therapy (IFT) and Group B were treated only with Scapula Stabilization Exercises and IFT. The duration of treatment was 4 weeks and they were assessed at baseline and after 4 weeks. Outcome measures included pain intensity by Visual Analog Scale (VAS) and Range of Motion (ROM) by goniometer. Results: Subjects in both Groups improved over 4 weeks after intervention. Significant $(p \leq 0.05)$ difference were found between both Groups after 4 weeks in VAS and ROM. But statistically $(\mathrm{p} \leq 0.05)$ greater change scores were found in the Group A for VAS and ROM than Group B. Discussion and Conclusion: Group A and B was effective in reducing pain and improving the ROM in patients with second stage of Frozen Shoulder. However, subjects in Group A, who re-
Prihvaćen/Accepted 20. 07. 2017. god.

ceived Trigger Point therapy and Myofascial release showed better improvement in reduce pain and improve the ROM than Group B. In conclusion the treatment program consisting of Trigger Point therapy and Myofascial release may be more effective in reducing pain and improving the ROM in second stage Frozen Shoulder among industrial workers.

Keywords: Frozen Shoulder, Trigger point therapy, Myofascial release therapy, Interferential therapy, Visual analogue scale, Range of motion, industrial workers.

\section{INTRODUCTION}

"Frozen shoulder" was first described by Duplayin 1872 but Codman in 1934 introduced the term frozen first time. He described painful shoulder as a condition of insidious onset that was associated with stiffness and difficulty in sleeping on the affected side. Nevisar described (1945) both the terminologies adhesive capsulitis and frozen shoulder are generally thought to be same. It is commonly affecting $2-5 \%$ of the industrial population typically between 40 and 60 years of age (1). The non-dominant arm is more likely to be involved (2), although about $12 \%$ of people are affected bilaterally (3).Other factors such as depression, immunologic factors, posture and occupation have been implicated in the aetiology (4).

Biochemical changes include alteration in immunoglobulin level and micro vascular supply of the supraspinatus tendon, with changes in the infracted tendon. Dense adhesions are present between the humeral head and the glenoid cavity. Adhesions increases as the disease progresses. The interval between the humeral 
head and the glenoid gets progressively narrowed capsular contracture is noticed. The dependent fold of the capsule gets obliterated with adhesions. The synovium is thickened, reddish and edematous. It has been found that volume of the joint is reduced, and the joint capsule is tight and contracted. It generally contracts the coracohumeral ligament and the shortened coracohumeral ligament restricts the external rotation (5).

The most commonly affected movements were external rotation and abduction of the gleno-humeral joint. Patients commonly complain of sharp pain reaching for the back pocket, combing the hair or dressing and decrease arm swing when walking (6). At rest the arm is often held in adduction and internal rotation, and the scapula of the affected side is usually elevated, laterally rotated and abducted (7).

Reeveshave described frozen shoulder passes through three phases such as freezing, frozen and thawing. Phase I- Pain: Patients have a gradual onset of diffuse shoulder pain, which is progressive over weeks to months. The pain is worse at night and is exacerbated by lying on the affected side. As the patient uses the arm less, pain leading to stiffness ensues. Phase IIStiffness: Patients seek pain relief by restricting movement. This heralds the beginning of the stiffness phase, which usually lasts 4 to 12 months. Patients describe difficulty with activities of daily living. As stiffness progresses, a dull ache is present nearly all the time (especially at night), and this often is accompanied by sharp pain during range of motion at or near the new end points of motion. Phase III- Thawing: This phase lasts for weeks or months, and as motion increases, pain diminishes. Without treatment motion return is gradual in most, but may never objectively return to normal, although most patients subjectively feel near normal, perhaps as a result of compensation or adjustment in ways of performing activities of daily living.

Lundberg developed a classification system of frozen shoulder based on the presence or absence of an inciting event. Primary Frozen shoulder: A condition in patients who report no inciting event and with no abnormality on examination (other than loss of motion) or plain radiographs. Secondary Frozen shoulder: A condition in patients with precipitant traumatic shoulder. An important feature of adhesive capsulitis is the decreased joint capacity. Normally, $16 \mathrm{~cm}^{3}$ of dye solution can be injected without resistance (8). A decreased joint capacity (less than $15 \mathrm{~cm}^{3}$ ) in combination with the characteristic restrictions of range of motion of the shoulder in lateral rotation, flexion in the sagittal plane, and abduction confirms the diagnosis of adhesive capsulitis (9).

Plain radiographs are usually unremarkable; there is normally an absence of bony X-ray changes. MRI has shown an increased blood flow to the synovium (10).
Treatment options include supervised physical therapy, non steroidal anti inflammatory medications, oral corticosteroids, intra-articular steroid injections, distention arthrography, closed manipulation, open surgical release, and arthroscopic capsular release. Initial treatment is non operative, with control of pain and inflammation, transcutaneous electrical nerve stimulation, and ultrasound may be helpful, combined with passive and active range-of-motion exercises (10).

Various techniques of massage and electrotherapeutic modalities produced positive outcome in patient with mixed shoulder disorders. Though individual effects of different treatment modalities are discussed in various studies, there is lack of evidence in understanding the combined effect of Trigger Point therapy and Myofascial release with physiotherapy methods. Thus the purpose of the study is to find out if there is any additional effect of Trigger Point therapy and Myofascial release when combined with conventional physiotherapy for second stage Frozen Shoulder to reduce pain and improve the range of motion.

\section{METHODS}

A Quasi Experimental Design [Comparative study] was conducted with random sampling method. Study was done on industrial workers with second stage frozen shoulder. Thirty $(n=30)$ subjects who fulfilled the inclusion and exclusion criteria were included and they were divided into two groups randomly (by flipping the coin). Group A was treated with Trigger Point therapy, Myofascial release, Scapula Stabilization Exercises, and Interferential Therapy $(n=15)$ and Group B was treated with Scapula Stabilization Exercises, and IFT only, $(\mathrm{n}=15)$ and treated for 6 sessions/ week for 4 weeks. ${ }^{4}$ Study was done in Out Patient Department of Physiotherapy, C.U. Shah physiotherapy college, Surendranagar, Gujarat, India.

Subjects for the study were selected based on the following inclusion criteria, having painful stiff shoulder for at least 3 months, limited ROM of shoulder joint (ROM losses of $25 \%$ or greater) in gleno humeral flexion, abduction, medial and lateral rotation, age group between 40-60 years, both genders, and Second Stage of Frozen Shoulder (11). Exclusion criteria consists of history of surgery on the particular shoulder, rheumatoid arthritis, painful stiff shoulder after severe trauma, fracture of the shoulder complex, rotator cuff rupture, tendon calcification, diabetes mellitus, intra articular steroid injection, first and third stage of Frozen shoulder and Osteoarthrosis (12).

Visual analogue scale (VAS) (Qualitative Outcome) and shoulder Range of Motion (Quantitative Outcome) as outcome measurements were taken before 
and after the Program Schedule. The VAS was used to measure the Subject's current level of pain intensity. Visual analogue scale (VAS) involves a 10 -cm horizontal line with "No pain" anchored at the left end and "Pain as bad as it could be" anchored at the right end. The patient was asked to place a mark on the line that represented the severity of his or her pain at the moment. The range of motion of the affected shoulders was assessed actively with a universal double-armed goniometer by placing the subjects in supine lying position. The measurements were taken for shoulder flexion, abduction, internal rotation and external rotation. Pain intensity and ROM were evaluated before and after treatment with VAS and Universal Goniometer.

\section{Procedure}

A total number of 45 subjects were screened out of which 30 subjects were selected for the study. Each subject was screened initially by using a simple selection proforma relevant to the inclusion and exclusion criteria. Those who fulfilled this selection criterion underwent a detailed physical examination of the shoulder for baseline assessment. Then the selected patients were randomly divided (flipping the coin) into two Groups of 15 each in Group A and B. The details and the purpose of the study were explained to all the patients and informed consent was obtained from each patient. The techniques are performed by specially trained physiotherapist for Trigger point therapy and myofascial release therapy.

The study has been approved by the institutional scientific and ethical committee. All the participants completed all the sessions of intervention (no drop outs). During the treatment sessions none of the patient's experienced any adverse effects.

Trigger Point Therapy (TPT): 15 minute/ sessions, 6 sessions per week, -4 weeks.

Subjects were asked to free from upper clothing and positioned comfortably in prone with both hands keep it under the head. Ischemic pressure is applied to the trigger points of supraspinatus, infraspinatus, teres major, and teres minor muscles. Apply firm digital ischemic compression to the trigger points sufficient to produce localized discomfort/pain as well as symptoms in the target area maintain this compression for 5 seconds (13). Release for 2-3 seconds. Reapply pressure (same level) and keep repeating it for 5 seconds. Two-three seconds off until the client reports a reduction in local or referred pain or an increase in pain (which is rare) or until 2 minutes have passed with no change in the pain levels. Repeat 1-3 for up to one minute and going deeper each time.

Myofascial release (MFR): 15 minute/ sessions, 6 sessions per week, -4 weeks.
After the muscles and trigger points have been released the whole area is revisited for fascial restrictions. Fascia is the membrane that surrounds entire muscles, muscle fibers, fibrils and smaller structures down to cellular level. There are numerous situations where fascia restricts movement without pain, in some cases of Frozen Shoulder. MFR uses specific techniques to release fascia, deep down into the joint (14). Land on the surface of the body with appropriate žtool' (knuckles, or forearm). Sink into the soft tissue. Contact the first barrier/restricted layer. Put in a žline of tension. Engage the fascia by taking up the slack in the tissue. Finally, move or drag the fascia across the surface while staying in touch with the underlying layers. Exit gracefully. Apply for 5seconds on and 2-3 seconds off until the client reports a reduction in local pain until $2 \mathrm{mi}-$ nutes.

Interferential Therapy: 6 days per week for 4 weeks.

It is one of the electrotherapeutic modality mainly applied for pain reduction. Instrument used is Biotech, India and 4 electrodes are placed around the shoulder with electrode gel. Carrier Frequency $3.85 \mathrm{KHz}$ and Pulse Duration $130 \mathrm{~ms}$ was set and it was applied for 20 minutes.

Scapular stabilization Exercise: $15 \mathrm{~min} /$ session, 6 session/week-4 weeks.

Prone row exercises, Overhead arm rise in line with lower trapezius muscle, Shoulder horizontal extension with external rotation, Perform 3 sets of exercise with low intensity ( $40 \%$ of maximum) for 30 repetitions with rest period of 1 minute.

\section{Statistical Analysis}

Descriptive statistics was done in the form of mean and standard deviation. Inferential statistics evaluated changes in VAS and ROM using unpaired t-test between the two groups and paired t-test was used to measure changes within group, analysis was done using SPSS version 18.0 (SPSS, Chicago, IL). Significance was accepted with $\mathrm{p}<0.05$.

\section{RESULTS}

Gender distribution: The gender distribution among 30 subjects who participated in Group A have 7 males $(23.33 \%)$ and 8 females $(26.67 \%)$ and Group B have 6 males (20\%) and 9 females (30\%).

Age distribution: Age distribution among $30 \mathrm{sub}-$ jects in both Group A and B is 51.6 and S.D \pm 4.561 .

Inter-group comparison of Pre VAS of Group A and B: After analysing the data calculated $U$ - value is 116.50 , and table $\mathrm{U}$ - value is 64 , the results shows that 
calculated $\mathrm{U}$ - value is greater than table $\mathrm{U}$ - value $(\mathrm{p}=$ 0.882 ), showing that there is no significant difference between pre values of VAS score of Group A and B score, so it shows that baseline data are homogenous.

Inter-group comparison of Post VAS of Group A and B: After analyzing the data the calculate U - value is 39.000 , and the table $U$ - value is 64 , the results shows that calculated $U$ - value is less than table $U$ - value showing that there is significant difference between post values of ROM of Group A and Group B VAS score. When comparing the percentage in reduction in VAS score, Group A shows $66.62 \%$ reduction in pain score compare to Group B 54.57\%.

Pre and Post Values VAS of Group A and Group B: For group A the mean of base line score of VAS is 7.40 and after 4 weeks the mean is 2.47 . For group B the base line means is 7.33 and after 4 weeks the score is 3.33 , it shows that there is reduction in VAS at the end of 4 weeks of treatment when compared to the first day. In Group A p-values is 0.001 and in Group B p-value is 0.000 in both the group $(p \leq 0.05)$, showing that $p$ value is significant. Statistical analysis shows in Group A $66.62 \%$ reduction in pain score and in Group B $54.57 \%$ reduction in pain score.

Inter- group comparison of Pre ROM of Group A and B: After analyzing the data the calculate $\mathrm{t}$ - value for flexion is 0.5472 , for abduction 0.2717 , for internal rotation 1.670 , for external rotation 1.376 , and the table $\mathrm{t}$ - value is 2.048 , the results shows that calculated $t$ - value is less than table $t$ value $(p>0.05)$ showing that there is no significant difference between pre values of ROM of Group A and Group B scores, so it shows that baseline data are homogenous.

Inter- group comparison of Post ROM of Group A and B: After analyzing the data the calculate t va- lue for flexion 3.443, for abduction 2.706, for internal rotation 2.737 , for external rotation 4.679 , and the table $\mathrm{t}$ - value is 2.048 , the results shows that calculated $\mathrm{t}$ - value is greater than table $\mathrm{t}$ - value showing that there is significant difference between post values of ROM of Group A and Group B scores. Statistical analysis shows in Group A 38.46\% improvement in flexion, $22.98 \%$ improvement in abduction, $36.22 \%$ improvement in internal rotation, and $20.94 \%$ improvement in external rotation, where as in Group B shows $27.28 \%$ improvement in flexion, $17.14 \%$ improvement in abduction, $21.46 \%$ improvement in internal rotation, and $11.83 \%$ improvement in external rotation. When comparing the percentage in improvement in ROM between Group A and Group B, shows there is more increase in ROM in Group A at the end of the treatment (after4 weeks) compare to Group B.

Pre and Post Values of ROM of Group A: The mean of base line of flexion is 82.93 and after 4weeks the mean is 120.26 . For abduction base line mean is 54.13 and after 4 weeks it is 83.06 , For internal rotation base line mean is 30.60 and after 4 weeks it is 44.87 , for external rotation the base line means is 17.40 and after 4 weeks it is 32.60 it shows that there is improvement in range of motion at the end of 4 weeks of treatment when compared to the first day in all the ranges. After analyzing the data the calculate $\mathrm{t}$ - value for flexion is 24.659 , for abduction is 20.292 , for internal rotation is 23.883 ,for external rotation is 27.448 , and the table $\mathrm{t}$ - value for all ROM is 2.145 , the results shows that calculated $\mathrm{t}$ value is greater than table $\mathrm{t}$ - value $(\mathrm{p} \leq 0.05)$, showing that there is a significant difference between the scores in pre and post test scores of Group-1. Statistical analysis shows $38.46 \%$ improvement in flexion, $22.98 \%$ improvement in abduction, $36.22 \%$ improvement in inter-

Table 1. Pre and post values of pain intensity and shoulder range of motion of Group A and Group B

\begin{tabular}{|c|c|c|c|c|c|c|}
\hline \multirow{2}{*}{ Study variables } & \multirow{2}{*}{ Group } & Baseline & 4 weeks & $\begin{array}{c}\text { Percentage } \\
\text { of Improvement }\end{array}$ & \multicolumn{2}{|c|}{ p-values } \\
\hline & & \multicolumn{3}{|c|}{ Mean value } & $\begin{array}{c}\text { Between } \\
\text { group }\end{array}$ & $\begin{array}{l}\text { Within } \\
\text { group }\end{array}$ \\
\hline \multirow{2}{*}{ Pain Intensity (VAS) } & A & 7.40 & 2.47 & $66.62 \%$ & \multirow{2}{*}{0.001} & \multirow{2}{*}{0.001} \\
\hline & B & 7.33 & 3.33 & $54.57 \%$ & & \\
\hline \multirow{2}{*}{ Shoulder flexion ROM } & A & 82.93 & 120.26 & $38.46 \%$ & \multirow{2}{*}{0.001} & \multirow{2}{*}{0.001} \\
\hline & B & 84.47 & 110.53 & $27.28 \%$ & & \\
\hline \multirow{2}{*}{ Shoulder Abduction ROM } & A & 54.13 & 83.06 & $22.98 \%$ & \multirow{2}{*}{0.001} & \multirow{2}{*}{0.001} \\
\hline & $\mathrm{B}$ & 53.13 & 74.87 & $17.14 \%$ & & \\
\hline \multirow{2}{*}{ Shoulder Int. Rot ROM } & A & 30.60 & 44.87 & $36.22 \%$ & \multirow{2}{*}{0.001} & \multirow{2}{*}{0.001} \\
\hline & $\mathrm{B}$ & 27.73 & 36.80 & $21.46 \%$ & & \\
\hline \multirow{2}{*}{ Shoulder Ext. Rot ROM } & A & 17.40 & 32.60 & $20.94 \%$ & \multirow{2}{*}{0.001} & \multirow{2}{*}{0.001} \\
\hline & $\mathrm{B}$ & 19.60 & 28.26 & $11.83 \%$ & & \\
\hline
\end{tabular}




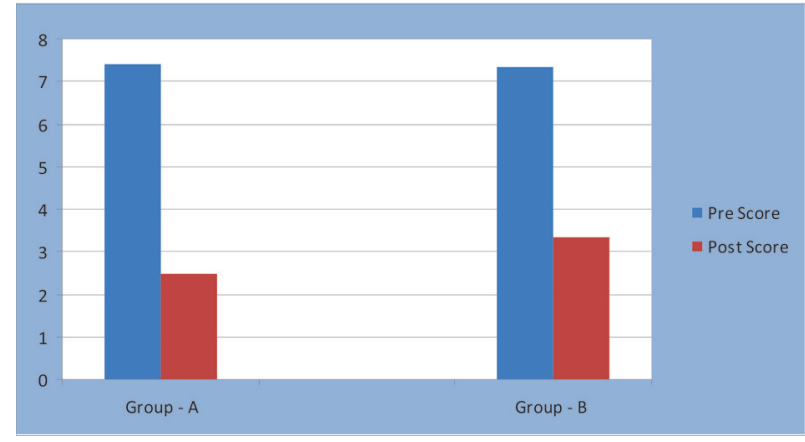

Figure 1. Pre and Post Mean of Visual Analog Scale score of Group $A$ and $B$

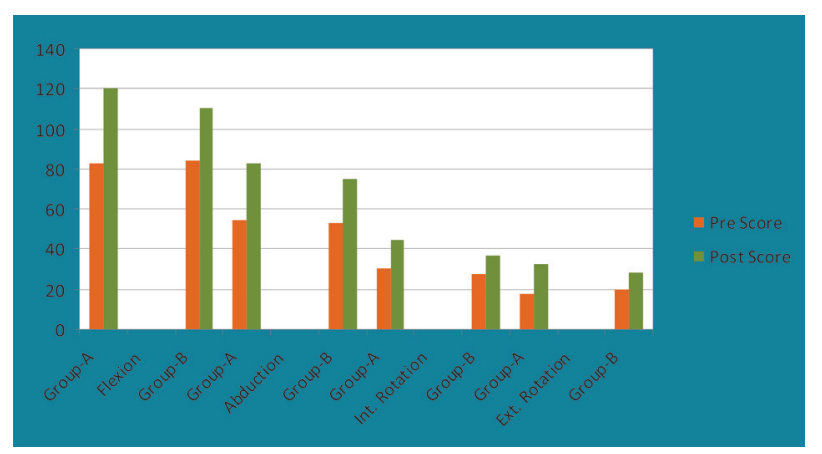

Figure 2. Pre and Post Mean of Shoulder flexion, Abduction, Int. rotation and Ext. rotation range score of Group $A$ and $B$

nal rotation, and $20.94 \%$ improvement in external rotation in Group A from the initial value.

Pre and Post Values of ROM of Group B: The mean of base line of flexion is 84.47 and after 4weeks the mean is 110.53 . For abduction base line mean is 53.13 and after 4 weeks it is 74.87 , For internal rotation base line mean is 27.73 and after 4 weeks it is, 36.80 for external rotation the base line mean is 19.60 and after 4 weeks it is 28.26 it shows that there is improvement in range of motion at the end of 4 weeks of treatment when compared to the first day in all the ranges.

After analyzing the data the calculate $\mathrm{t}$ - value for flexion is 70.226 for abduction is 58.551 , for internal rotation is 16.060 , for external rotation is 19.255 , and the table $\mathrm{t}$ - value for all ROM is 2.145 , the results shows that calculated $t$ - value is greater than table $t$ value $(\mathrm{p} \leq 0.05)$, showing that there is a significant difference between the scores in pre and post test scores of Group B. Statistical analysis shows $27.28 \%$ improvement in flexion, $17.14 \%$ improvement in abduction, $21.46 \%$ improvement in internal rotation, and $11.83 \%$ improvement in external rotation in Group B from the initial value (Table 1, Figure 1 and 2).

\section{DISCUSSION}

Frozen Shoulder is characterized by painful stiffness of the shoulder that may persist for several years.
It is a common disorder; with an estimated annual incidence of $3 \%$ to $5 \%$ in the industrial population (15). Advocated treatments include rest and analgesics, corticosteroid injections, acupuncture, physical therapy, manipulation under anaesthesia, and arthroscopic or open surgery. There is no general acceptance of one standard treatment.

The study was conducted on 30 patients with two groups of 15 each. Group A was intervened with Trigger Point therapy, Myofascial release, Scapula Stabilization Exercises, IFT whereas Group B was intervened with Scapula Stabilization Exercises and IFT only. Outcome measures measured Pain Intensity by Visual Analog Scale and Range of Motion by goniometer measured prior to treatment (Pre-Rx) and at the end of 4 weeks of treatment.

$1^{\text {st }}$ objective of this study was to find the effectiveness of trigger point therapy and myofascial release combined with IFT, and scapula stabilization exercises in second stage of frozen shoulder to reduce pain and improve the range of motion. In Group A its overall effectiveness on VAS score was found using Wilcoxon test, after 4 weeks of treatment which shows $p$ value $=$ 0.001 , which is significant. ROM was found using paired t-test which shows $p=0.000$ which is very highly significant for all shoulder ranges after 4 weeks of treatment. This suggests that trigger point therapy and myofascial release combined with conventional treatment is effective in reducing pain and improving the Range of motion.

The $2^{\text {nd }}$ objective of this study was to find the effectiveness of Scapula Stabilization Exercises and IFT on second stage frozen shoulder. In Group B subjects who received Scapula Stabilization Exercises and IFT its overall effectiveness on VAS score was found using Wilcoxon test after 4 weeks of treatment which shows $p=0.001$, which is significant. ROM was found using paired t-test which shows $p=0.000$ which is significant for all shoulder ranges after 4 weeks of treatment. This suggests that conventional treatment is effective in to reduce pain and improve the Range of motion.

The $3^{\text {rd }}$ objective of the study was to compare the effectiveness of Trigger point therapy, Myofascial release, Scapula Stabilization Exercises and IFT (Group A) over Scapula Stabilization Exercises and IFT (Group B) in the management of second stage frozen shoulder. The intergroup comparison of VAS Score was done using Mann Whitney test which showed 'p' significant after four weeks of treatment, Comparison of ROM of both Group A and Group B was done using independent $t$-test which showed ' $p$ ' value significant for all the ranges.

Statistical analysis shows when comparing the percentage of reduction in VAS score between Group 
A and Group B, Group A shows $66.62 \%$ reduction in pain score when compare to Group B (54.57\%). Statistical analysis shows in Group A $38.46 \%$ improvement in flexion, $22.98 \%$ improvement in abduction, $36.22 \%$ improvement in internal rotation, and $20.94 \%$ improvement in external rotation, where as in Group B $27.28 \%$ improvement in flexion, $17.14 \%$ improvement in abduction, $21.46 \%$ improvement in internal rotation, and $11.83 \%$ improvement in external rotation. When comparing the percentage in improvement in ROM between Group A and Group B, Group A shows more increase in ROM at the end of the treatment (after 4 weeks) compare to Group B.

The results of this study supported the experimental hypothesis that there is significant difference between the Trigger Point therapy and Myofascial release combined with conventional treatment versus conventional treatment alone in the treatment of second stage of Frozen Shoulder. On further analysis it also supported the hypothesis that there is significant difference in effectiveness of Trigger Point therapy and Myofascial release combined with conventional treatment versus conventional treatment alone in the treatment of second stage of frozen Shoulder.

Our results support the study of Susan Jackson et al conducted a study on frozen shoulder treatment of the myofacial release at Auburn Hospital and Concord Repatriation General Hospital in Sydney, Australia; over second stage frozen shoulder patients $(n=29)$, with help of MFR And Trigger point therapy and concluded that following a, Soft-tissue massage improved range of motion, reduced pain and improved function in people with shoulder pain (13). S Niel-Asheret al conducted a study on Frozen Shoulder Syndrome: a novel manipulative approach at the London frozen shoulder clinic (private); over Second stage frozen shoulder patients $(\mathrm{n}=100)$ with help of soft tissue treatment (MFR) concluded that this technique may have a significant role in improved range of motion, reduced pain the management of frozen shoulder syndrome (16).

In Trigger Point Therapy, ischemic pressure may be applied to the trigger points in the painful area (13). Pressure on the trigger point stops blood from flowing into the affected area making it ischemic (deprived of oxygen) (13).The person should feel a "comfortable pain" as if pressure is being released. After 5 seconds the pressure is released and the circulation of blood, oxygen and nutrients to the area increases (13).In addition, it is important to apply general massage to the surrounding muscles of the shoulder, this helps keep the shoulder functioning correctly and speeds up the reha- bilitation process (13). From this study it can be said that Trigger Point therapy and Myofascial release combined with conventional treatment can be used as additional method of choice for the treatment of patient with frozen shoulder.

\section{CONCLUSION}

The results indicate that both experimental and control groups are effective in the second stage of Frozen Shoulder to reduce pain and improve the Range of motion. However, the subjects in the experimental group, who received Trigger Point therapy and Myofascial release showed better improvement in reducing pain and improving the ROM than the control group. In conclusion the treatment program consisting of Trigger Point therapy and Myofascial release may be more effective in the second stage of Frozen Shoulder to reduce pain and improve the Range of motion among industrial workers.

\section{Limitations of the study}

The main limitation of this study was its small sample size. A larger sample would be required to validate and generalize the results of this study to the population. Further the design did not support long-term follow-up of the patients after the study, to understand the long term benefits even after completion of the study.

\section{Recommendations for future study}

The effectiveness of other types of exercise programs can be trailed and the same study can be done with a longer follow-up. Other outcome measures such as functional level, depression status and quality of life can also be measured in the future study.

\section{Acknowledgement}

The authors thank all elderly who participated in this study.

\section{Declaration of interest}

The authors declare no competing interests.
Abbreviations
IFT - Interferential Therapy
VAS - Visual Analog Scale
ROM - Range of Motion 


\title{
Sažetak
}

\section{DODATNI EFEKAT TERAPIJE TACAKA OKIDANJA I TEHNIKE MIOFASCIJALNOG OSLOBAĐANKA NA DRUGI STADIJUM SMRZNUTOG RAMENA MEĐU INDUSTRIJSKIM RADNICIMA}

\author{
Nambi S. Gopal, ${ }^{1}$ Abdelbasset M. Kamal Walid ${ }^{1,2}$ \\ Department of physical therapy and health rehabilitation, College of Applied Medical Sciences, \\ Prince Sattam Bin Abdul Aziz University, Al-Kharj, Saudi Arabia \\ ${ }^{2}$ Department of physical therapy, Kasr Al-Aini Hospital, Cairo University, Egypt
}

Uvod i cilj: Sindrom smrznutog ramena je često stanje koje obično zahvata $2-5 \%$ industrijske populacije, tipično između 40-60 godina starosti. Većina studija je analizirala na osnovu pojedinačne intervencie, i nije ispitivala kombinacije intervencija. Cilj ovog rada bio je da se ispitaju dve različite tehnike masaže, terapija tačke okidanja i tehnika miofascijalnog oslobađanja, u drugom stadijumu smrznutog ramena, kako bi se smanjili bolovi i povećala širina pokreta. Pacijenti: U studiju je uključeno 30 osoba koje su radile $\mathrm{u}$ industriji sa unilateralnim smrznutim ramenom $\mathrm{u}$ drugom stadijumu, koje je trajalo 3 ili više meseci unazad i sa padom pasivne pokretljivosti zgloba u iznosu od $25 \%$ ukupne pokretljivosti zgloba u poređenju sa pokretljivošću ramena druge strane. Metode: Pacijenti koji su ispunjavali kriterijume su svojevoljno pristali da učestvuju u studiji, i bili su nasumično raspoređeni u dve grupe, A i B. Grupa A je bila lečena terapijom tačke okidanja, tehnikom miofascijalnog oslobađanja, vežbama stabilizacije skapule i interferentnom terapijom (IFT), a Grupa B je lečena samo vežbama stabilizacije skapule i IFT. Dužina tretmana je bila 4 nedelje, i stepen pokretljivosti zgloba je bio procenjivan na početku i 4 nedelje nakon početka od-

\section{REFERENCES}

1. Grubbs N. Frozen shoulder syndrome - a review of literature. J Orthop Sports Phys Ther.1993; 18(3): 479-87.

2. Fareed DO, Gallivan WR. Office management of frozen shoulder syndrome: treatment with hydraulic distension under local anaesthesia. Clin Orthop. 1989; 242: 177-83.

3. Wadsworth CT. Frozen Shoulder. Phys Ther. 1986; 66(12): 1878-83.

4. Murnaghan JP. Frozen Shoulder. In: Rockwood CA, Matsen FA, editors. The Shoulder. $1^{\text {st }}$ ed. Philadelphia:W.B. Saunders Co; 1990. p. 837-62.

5. S. Terry Canale, James H. Beaty. Campbell's Operative Orthopaedics. Vol 3; $11^{\text {th }}$ ed. Philadelphia, PA, 2007: 27-9.

6. Kesler RM. The Shoulder. In: Kesler RM, Hertling D, editors. Management of Common Musculo-Skeletal Disorders. Philadelphia: Harper and Row; 1983. p. 274-310.

7. Reeves B. The natural history of the frozen shoulder Scand J Rheumatol: 1975; 4(4): 193-6. govarajuće terapije. Ishodna merenja su uključivala Analog Vizuelne Skale (VAS) i opseg pokreta (ROM) pomoću goniometra. Rezultati: Pacijenti obe grupe su napredovali tokom 4 nedelje nakon intervencije. Značajna razlika je nađena prilikom poređenja obe grupe nakon 4 nedelje i u VAS i u ROM parametru. Ali, statistički značajno veći skor promene je nađen u Grupi A za VAS i ROM nego u grupi B. Diskusija i zaključak: Tretman primenjen na grupama A i B bio je efektan u smanjenju bola i u popravljanju opsega pokreta (ROM) kod pacijenata u drugom stadijumu smrznutog ramena. Međutim, pacijenti grupe A, koji su imali terapiju tačke okidanja i tehniku miofascijalnog oslobađanja, pokazali su bolji napredak u smanjenju bola i napredovanju ROM nego u Grupi B. U zaključku se može reći da tretman koji je činila terapija tačke okidanja i tehnika miofascijalnog oslobađanja je efektnija u smanjenju bola i popravljanju opsega pokreta u drugom stadijumu sindroma smrznutog ramena među industrijskim radnicima.

Ključne reči: Smrznuto rame, terapija tačaka okidanja, tehnika miofascijalnog olsobađanja, Interferentna terapija, Vizuelno analogna skala, obim pokreta, industrijski radnici.

8. Neviaser JS. Arthrography of the shoulder joint: study of the findings in Adhesive Capsulitis of the Shoulder. J Bone Joint Surg Am. 1962; 44(A): 1321-30.

9. Vermeulen HM, Obermann WR, Burger BJ, Kok GJ, Rozing PM, van Den Ende CH. End-range mobilization techniques in adhesive capsulitis of the shoulder joint: A multiple-subject case report. Phys Ther. 2000; 80(12): 1204-13.

10. S. Terry Canale, James H. Beaty. Campbell's Operative Orthopaedics. Volume 3; 11 th ed. Philadelphia, PA, 2007: 25-7.

11. Kelley MJ, McClure PW, Leggin BG. Frozen Shoulder:Evidence And A Proposed Model Guiding Rehabilitation; Journal Of Orthopaedic And Sports Physical Therapy. 2009: 39(2): 135-48.

12. Yang JL, Chang CW, Chen SY, Wang SF, Lin JJ. Mobilization techniques in subjects with frozen shoulder syndrome: randomized multiple treatment trial. Phys Ther. 2007; 87(10): 1307-15.

13. John Sherwin. Impact of Massage Therapy on Treatment of Adhesive Capsulitis. Massage therapy foundation. 2012; 847-89. 
14. Barnes JF. Myofascial Release: The Search for Excellence, a Comprehensive Evaluatory and Treatment Approach. Paoli, PA: Rehab Services. InInc. \& Myofascial Release Seminar 1990.

\section{Correspondence to / Autor za korespondenciju}

Gopal Nambi S. Asst.Professor,

Dept of Physical Therapy and Health Rehabilitation,

College of Applied Medical Sciences,

Prince Sattam Bin Abdul Aziz University,

Al-Kharj, Saudi Arabia.

E - mail: physio_gopal@rediffmail.com

Mob No: + 966501878382
15. Bridgman JF. Periarthritis of the shoulder and diabetes mellitus. Ann Rheum Dis. 1872; 31(1): 69-71.

16. Grubbs N. Frozen shoulder syndrome - a review of literature. JOSPT 1993; 18(3): 479-87. 